\title{
Vanglakiusamise kirjeldav analüüs ühe Eesti meestevangla näitel
}

\author{
Kristi Kõiv ${ }^{{ }^{1}}$ \\ ${ }^{a}$ Tartu Ülikooli haridusteaduste instituut
}

\begin{abstract}
Annotatsioon
Võitlus kiusamisega mistahes kontekstis (k.a vangla) saab alguse selle olemuse väljaselgitamisest. Selleks püstitati kaks eesmärki: 1) kirjeldada vanglakiusamise olemust ja ulatust, lähtudes kahest aspektist - teiste kinnipeetavate kiusamine ja kiusamise ohvriks langemine, ning 2) võrrelda kiusajate, ohvrite, kiusajate/ohvrite ja kiusamisega mitteseotud kinnipeetavate gruppide personaalseid ja käitumuslikke karakteristikuid ning reaktsioone kiusamisele ühe Eesti meestevangla näitel. Uuritavateks oli 110 täiskasvanud meessoost kinnipeetavat, kes täitsid enesekohase ankeedi DIPC-R (Ireland, 2002a), millega mõõdetakse vanglakiusamisele iseloomulikku käitumist. Tulemused näitavad, et selles kinnipidamisasutuses oli prevaleerivaks kiusamisliigiks kaudne kiusamine. Uuringust nähtub, et 77\% uuritud kinnipeetavatest oli seotud kiusamisega kas kiusaja/ohvri (43\%), ohvri (20\%) või kiusaja (14\%) staatuses, mis viitab vanglakiusamise laiaulatuslikkusele. Uurimisandmed võimaldavad võrrelda kiusamisega seotud uuritavate gruppide personaalseid ja käitumuslikke karakteristikuid ning reaktsioone kiusamisele, kõrvutades neid varasemate tulemustega samas valdkonnas.
\end{abstract}

Võtmesõnad: kiusamine, täiskasvanud meessoost kinnipeetavad, enesekohane meetod, DIPC-R

\section{Sissejuhatus}

Kiusamistemaatika on uurijaid köitnud juba üle 30 aasta, saades alguse koolikiusamise uurimustest ja hõlmates tänapäeval uurimusi mitte ainult kooli, vaid ka teiste kontekstide kohta, näiteks kiusamine töökohal, hoolekandeasutuses, koolieelsetes lasteasutustes, käimissuhetes, kodus, vanglas (Monks \& Coyne, 2011). Kiusamisele vanglas kui eraldiseisvale 
uurimisvaldkonnale vanglavägivalla kõrval (nt Edgar, O’Donnell, \& Marti, 2011) hakkasid uurijad tähelepanu pöörama kaks aastakümmet tagasi, mil tehti esimesed uuringud noormeeste seas Kanada (Connell \& Farrington, 1996) ja Inglise vanglates (McGurk \& McDougall, 1991) ning täiskasvanud meeste ja naiste seas Inglise vanglates (Ireland \& Archer, 1996). Huvi vanglakiusamise vastu on püsivalt suurenenud nii esimese kümnendi (Monks et al., 2009) kui ka teise kümnendi jooksul (Ireland, 2011) ning juhtivaks selles valdkonnas on jäänud Inglismaa, kuid üha rohkem uuritakse tänapäeval vanglakiusamist ka teistes riikides: Iirimaal (Leddy \& O'Connell, 2002), Eestis (Kõiv \& Maasikas, 2014), Kanadas (Ireland \& Power, 2013), Pakistanis (Tahir, 2011), Šotimaal (Beck, 1994; Dyson, 2005; Kiriakidis, 2009; Power, Dyson, \& Wozniak, 1997), Taanis (Blaauw, 2005), USAs (Listwan, Colvin, Hanley, \& Flannery, 2010).

Vanglakiusamist puudutavas teaduskirjanduses toetuti selle valdkonna uurimise alguses koolikiusamise definitsioonidele (nt Connell \& Farrington, 1996), kus kiusamist käsitleti kui agressiivse käitumise vormi, millele on omane korduvus, tahtlikkus ja jõudude tasakaalutus (Farrington, 1993). Eelnimetatud kolme tunnuse olemasolu ja sobivus kiusamise defineerimiseks vangla kontekstis on kahtluse alla seatud (Ireland, 2005a; Ireland \& Ireland, 2003) ning kiusamist vanglas defineeritakse agressiooni alavormina laialdasemalt. „Indiviide kiusatakse, kui nad on olnud nädala jooksul ühe või erinevate agressorite otsese ja/või kaudse agressiooni ohvriks. Üksikuid agressioonijuhte vaadeldakse kiusamisena, eriti kui need on tõsised ja kui indiviidid usuvad või kardavad, et neil on risk langeda ühe või erinevate agressorite ohvriks. Juhtu peetakse kiusamiseks, kui ohver usub, et tema vastu rakendati agressiooni, hoolimata sellest, kas kiusaja käitumine oli tahtlik või mitte. Kiusamine on ka see, kui jõudude tasakaalutus kiusaja ja ohvri vahel esineb varjatult või pole otseselt nähtav" (Ireland, 2002b, 1k 26).

\section{Vanglakiusamise olemus ja ulatus}

Vanglakiusamine jagatakse otseseks ja kaudseks. Otsene kiusamine puudutab kiusaja avalikku negatiivset käitumist ohvri suhtes, nagu füüsiline, verbaalne, seksuaalne, psühholoogiline ja vargustega seotud agressioon (Ireland \& Archer, 1996). Kaudne kiusamine hõlmab varjatumaid, mitte näost näkku toimuvaid agressiooniakte, nagu tagarääkimine või tahtlik sotsiaalne tõrjumine (Ireland, 2000). Lisaks saab vangla kontekstis välja tuua ka nn sunniviisilise (coersive) kiusamise, mis seisneb surve avaldamises teisele kinnipeetavale, et ta teeks midagi või täidaks antud ülesannet, nt teise kinnipeetava kambri koristamine (Ireland, 2005b). Kaudset kiusamist 
vanglas kaldub esinema ulatuslikumalt kui otsest kiusamist (Holland, Ireland, \& Muncer, 2009; Ireland, 1999a; Ireland \& Ireland, 2000; Ireland \& Monaghan, 2006), otsese ja kaudse vanglakiusamise ulatusega seotud soolisi erinevusi täiskasvanute vahel ei ole täheldatud (Ireland, Archer, \& Power, 2007). Sunniviisiline kiusamine vanglas on otsese ja kaudse kiusamisega võrreldes osutunud kõige vähem ulatuslikuks (Ireland, 2005b; Ireland \& Qualter, 2008).

Kui vaadelda vanglakiusamise ulatust, lähtudes teiste kinnipeetavate kiusamise ohvriks langemise (ohvrikäitumise) ja teiste kinnipeetavate kiusamise (kiusamiskäitumise) ulatusest, siis ilmneb, et keskmiselt 53\% kinnipeetavatest on seotud ohvrikäitumisega ja 52\% kiusamiskäitumisega (Ireland, 2005a). Otsese vanglakiusamise liikide seas kaldub olema sagedasim verbaalne ja/või psühholoogiline kiusamis- ja ohvrikäitumine, kusjuures seksuaalne agressioon osutub kõige vähem sagedaseks (Ireland \& Bescoby, 2005; Ireland \& Ireland, 2000; Ireland \& Power, 2004; Ireland \& Rowley, 2007; South \& Wood, 2006).

\section{Vanglakiusamises osalevad kinnipeetavate grupid}

Koolikiusamist puudutavad kirjalikud küsimustikud, mille eesmärk on välja selgitada kiusamises osalejate rollid, on põhiliselt kahesugused: kas enesekohased või eakaaslaste hinnangutel põhinevad (nt Cornell \& Brockenbrough, 2004), ning need võimaldavad kindlaks teha nii kiusajad, ohvrid kui ka kõrvalseisjad. Vanglas eakaaslaste hinnangutel põhinevaid meetodeid kasutada ei saa, sest teiste kinnipeetavate kohta info andmisel kehtivad vangla subkultuurilise koodina piirangud ning vanglad on enamasti koosseisult suuremaarvulised ja rohkem muutuvad kui koolid (Ireland, 2011). Enesekohastele küsimustikele tuginedes saab uurija määrata kindlaks vanglakiusamisega seotud kinnipeetavate grupid: kiusajad, ohvrid, kiusajad/ ohvrid ja kiusamisega mitteseotud kinnipeetavad (nt Ireland, 1999a). Irelandi (2011) kokkuvõtvatele tulemustele toetudes saab väita, et vanglas on kõige arvukamalt esindatud kiusajate/ohvrite grupp (kinnipeetavad, kes kiusavad teisi ja on samal ajal ise kiusatavad), kuhu olenevalt konkreetsest uuringust kuulub 40-45\% kiusamisega seotud kinnipeetavatest ning kus kiusajaid on keskmiselt 15\% ja ohvreid 20\%.

Kinnipeetavate jagamine gruppideks vanglakiusamisega seotust või mitteseotust arvesse võttes võimaldab välja selgitada kinnipeetavate personaalsed ja käitumuslikud karakteristikud, mis ennustavad, kas kinnipeetav kuulub kiusamisega seotud gruppi (kiusajad, ohvrid, kiusajad/ohvrid) või kiusamisega mitteseotud gruppi, seejuures on leitud, et käitumuslikud 
tunnusjooned on grupikuuluvuse ennustamisel personaalsete tunnustega võrreldes reliaablimad (Ireland, 2011). Nimelt ennustavad kinnipeetavate personaalsed karakteristikud (vanus, rahvus, kinnipidamisaja pikkus, süüteo liik) vanglakiusamisega seotust (kiusaja, ohvri ja kiusaja/ ohvri saatust) või mitteseotust ebajärjekindlat. Kõige järjekindlamat on leitud seoseid kinnipeetava pikema kinnipidamisasutuses viibitud aja ja kiusajate/ohvrite gruppi kuulumise vahel (Ireland, 2005a) ning suurema arvu vahistamiskordade ja kiusajate gruppi kuulumise vahel (nt Power et al., 1997). Mõnedest uurimustest nähtub, et ohvrid kalduvad olema vanemad kui ülejäänud kiusamisega seotud kinnipeetavate gruppi kuulujad (Ireland, 1999a; Leddy \& O'Connell, 2002; South \& Wood, 2006). Seevastu uurimused, milles püütakse eristada vanglakiusamisega seotud kinnipeetavate gruppide liikmeid nende süüteo liigi järgi, on tulemustes ebajärjekindlad leidub uurimusi, kus ei täheldata kinnipeetavate gruppide vahel erinevust (South \& Wood, 2006) või kus ohvrite grupil esineb teiste gruppidega võrreldes vähem vägivallakuritegusid (Ireland, 1999a; Power et al., 1997) ja kiusajate/ohvrite vägivallakuriteod on teiste gruppidega võrreldes sagedasemad (Ireland, 1999a).

Kinnipeetavate käitumuslikke karakteristikuid on uuritud kolmest aspektist: negatiivne käitumine (vanglapersonali või vanglareeglite vastu), uimastitega seotud käitumine (uimastite ostmine, müümine, tarvitamine) ja positiivne käitumine (nt teiste kinnipeetavate aitamine, sõprade leidmine). Kõige püsivama leiuna on ilmnenud asjaolu, et kiusajatel/ohvritel esineb vanglas sagedamini negatiivset käitumist kui teistel gruppidel (Ireland, 2011). Samal ajal on leitud, et kiusajate/ohvrite gruppi kuulujaid iseloomustab sage ja ohvrite gruppi kuulujaid harv positiivne käitumine vanglas (Ireland, 2001) ning kiusamisega mitteseotute nii positiivne kui ka negatiivne käitumine on teiste gruppidega võrreldes üldjuhul harvem (Ireland et al., 2007). Sagedamini ilmnes uimastitega seotud käitumist (meessoost) kinnipeetavatest koosneval kiusajate/ohvrite grupil ja harvem kiusamisega mitteseotutel (Ireland, 2001; Ireland et al., 2007; Archer, Ireland, \& Power, 2014).

Uuritud on ka kiusamisega seotud kinnipeetavate gruppide liikmete reaktsioone kiusamisel. Uurimistulemused näitavad, et ohvrite reaktsioonid on seotud peamiselt hirmu, vältimise ja enesevigastustega ning kiusajate ja kiusajate/ohvrite reaktsioonid otsese ja kaudse agressiooniga (Archer et al., 2014). Võrreldes ohvrite ja kiusamisega mitteseotud kinnipeetavate reaktsioone kiusamise korral, ilmnes, et ohvrite reaktsioonid on sagedasemad, seejuures on ülekaalus vältivad (nt kambrisse jäämine, teise kambrisse kolimine) ja enesekaitsega seotud reaktsioonid (Ireland \& Ireland, 2000). 
Kiusamist vanglas on uuritud mitmete meetoditega, mille hulka kuuluvad individuaalsed intervjuud (nt Connell \& Farrington, 1996), fookusgrupi intervjuud (nt Ireland \& Hill, 2001; Spain, 2005), ametlik statistika (Power et al., 1997) ja enesekohased küsimustikud. Vanglakiusamist käsitlevates uuringutes, kus on kasutatud enesekohaseid küsimustikke, on olnud fookuses eelkõige täiskasvanud mehed (Allison \& Ireland, 2010; Archer \& Southall, 2009; Brewer, 2010; Holland et al., 2009; Ireland \& Ireland, 2000; Ireland \& Power, 2013; Ireland \& Qualter, 2008; Listwan, Colvin, Hanley, \& Flannery, 2010; Palmer \& Thakordas, 2005; South \& Wood, 2006; Turner \& Ireland, 2010; Wood, Moir, \& James, 2009). Vähem on uuritud noormehi (Grennan \& Woodhams, 2007; Ireland, 1999a, 2005b) ning täiskasvanud ja noorukiealisi meessoost kinnipeetavaid (Ireland \& Power, 2004; Kõiv \& Maasikas, 2014). Leidub ka hulk uurimusi, kus uuritavateks on mõlemast soost täiskasvanud kinnipeetavad (Archer, Ireland, \& Power, 2007, 2014; Ireland, 1999a, 2001, 2002c; Ireland et al., 2007; Ireland \& Ireland, 2008; Tahir, 2011) või mõlemast soost täiskasvanud ja noorukiealised (Ireland, 1999b). Ainult üksikutes uurimustes on uuritavateks naised (Nelson, Woodhams, \& Hatcher, 2010). Eestis on vanglakiusamise uurimine alles algusjärgus, kuid selleks, et kiusamisvastane ennetus- ja sekkumistöö oleks tõhus, tuleb tunda kiusamise eripära eri kontekstides ning arvestada kiusajate ja ohvrite personaalsete ja käitumuslike tunnusjoonte kui riskiteguritega, samuti vangla kui kinnise institutsionaalse keskkonnaga.

Praegusel uurimusel on kaks eesmärki: 1) kirjeldada vanglakiusamise olemust ja ulatust seoses otsese, kaudse ja sunniviisilise kiusamisega, lähtudes kahest aspektist - teiste kinnipeetavate kiusamine ja kiusamise ohvriks langemine, ning 2) võrrelda kinnipeetavate personaalseid ja käitumuslikke karakteristikuid ning reaktsioone kiusamisele kinnipeetavate gruppide (kiusajate, ohvrite, kiusajate/ohvrite ja kiusamisega mitteseotud kinnipeetavate) lõikes ühes Eesti kinnises kambervanglas uuritud valimi põhjal.

Töö eesmärke arvesse võttes püstitatakse kaks uurimisküsimust.

1. Kui ulatuslik on otsene, kaudne ja sunniviisiline vanglakiusamine, lähtudes kahest aspektist - teiste kinnipeetavate kiusamine (kiusamiskäitumine) ja kiusamise ohvriks langemine (ohvrikäitumine) Eesti ühes kambervanglas uuritud meessoost kinnipeetavate seas?

2. Kas personaalsed karakteristikud (vanus, rahvus, õigusrikkumise liik, karistusaja pikkus), käitumuslikud karakteristikud (negatiivne, positiivne, uimastitega seotud käitumine) ja reaktsioonid kiusamisele eristavad uuritud meessoost kinnipeetavate gruppe, kes on seotud vanglakiusamisega ühes Eesti kambervanglas? 


\section{Meetod}

\section{Uurimisinstrument}

Kiusamiskäitumise uurimiseks vanglas kasutati küsimustikku Direct and Indirect Prisoner Behaviour Checklist - Revised (DIPC-R@): Ireland, 2002a; autori loal), mis kohandati eesti ja vene keele tarbeks. DIPC-R on ümbertöötatud versioon DIPC küsimustikust (Ireland, 1999a), millega mõõdetakse vanglakiusamisele iseloomulikku käitumist. Peale otsese kiusamise (füüsilise, verbaalse, vargustega seotud, seksuaalse ja psühholoogilise kiusamise) ja kaudse kiusamise võimaldab DIPC-R mõõta ka sunniviisilist kiusamist kahest aspektist: teiste kinnipeetavate kiusamine (kiusamiskäitumine) ja kiusamise ohvriks langemine (ohvrikäitumine). Küsimustikus ei kasutata terminit kiusamine ja uuritavatele esitatakse mitmeid agressiivsete käitumisaktide kirjeldusi, mis puudutavad nii teiste kinnipeetavate kiusamist kui ka teiste kinnipeetavate poolse kiusamise ohvriks olemist. DIPC-R koosneb 144 küsimusest, millest 56 kirjeldavad ohvrikäitumist ja 55 kiusamiskäitumist. 33 küsimusega mõõdetakse positiivset (5 küsimust), negatiivset (5 küsimust) ja uimastitega seotud käitumist (4 küsimust) ning reaktsioone kiusamise korral (10 küsimust), ülejäänud on täiteküsimused.

Kõik küsimused küsimustikus on jaotatud kahte ossa. Esimene osa puudutab ohvrikäitumist, näiteks „Mind on nimetatud minu rahvust puudutavate sõimunimedega” (verbaalne), „Mind on tahtlikult tõugatud või lükatud” (füüsiline), „Mind on sunnitud tegema tööd, mida peab tegema teine kinnipeetav” (sunniviisiline), „Mind on hirmutatud” (psühholoogiline). Küsimused teises küsimustiku osas on seotud teiste kiusamisega, näiteks „Olen tahtlikult kedagi ignoreerinud” (kaudne), „Olen kedagi seksuaalselt ahistanud” (seksuaalne), „Olen tahtlikult alustanud kaklust kellegagi” (füüsiline). Uuritavatele antakse nimekiri erinevatest käitumisaktidest, mis iseloomustavad vanglakiusamist, ja neil palutakse märgistada käitumisaktid, millega nad on viimase nädala jooksul kokku puutunud, vastates kas „ei” või ,jah”.

DIPC-R võimaldab uuritavaid liigitada ühe kategooria alla neljast, olenevalt sellest, kas uuritavad on seotud vanglakiusamisega või mitte. Kategooriasse „Kiusaja” kuuluvad need uuritavad, kes märgistavad vähemalt ühe kiusamiskäitumise küsimuse ja mitte ühtki ohvrikäitumise küsimust. Kategooria „Kiusaja/ohver” alla paigutuvad need, kes märgistavad küsimustikus vähemalt ühe kiusamisküsimuse ja vähemalt ühe ohvriküsimuse. Kategooriat „Ohver” esindavad need uuritavad, kes märgistavad vähemalt ühe ohvrikäitumist puudutava küsimuse ja mitte ühtki kiusamiskäitumist märkivat küsimust. Kategooria „Kiusamisega mitteseotud” alla loetakse need uuritavad, kes ei märgi seotust ühegi kiusamis- ega ohvrikäitumise aktiga. 
Küsimustikus on neli küsimust, mis puudutavad uimastite tarvitamist, müümist ja ostmist (nt „Olen süstinud uimastavaid aineid”), ning viis küsimust, mis märgivad negatiivset käitumist vanglapersonali ja kinnipidamisasutuses kehtivate reeglite suhtes (nt „Olen solvanud personaliliiget”). Viis küsimust käsitlevad positiivset käitumist vanglas (nt „Olen aidanud uuel kinnipeetaval kohaneda”) ja kümme küsimust kirjeldavad reaktsioone kiusamise korral (nt „Olen löönud kedagi pärast seda, kui mind on narritatud või teist moodi kiusatud”). Küsimustik sisaldas ka lisaküsimusi kinnipeetavate vanuse, rahvuse, praeguse karistusaja pikkuse ja elu jooksul kinnipidamisasutuses viibitud aja ning süüteo liigi kohta.

Praeguse uurimuse raames rakendati DIPC-Ri küsimustiku eesti- ja venekeelset varianti. Kirjaliku küsimustiku kohandamisel nii eesti kui ka vene keele tarbeks kasutati tõlke-tagasitõlke meetodit kahes etapis. Kaks sõltumatut tõlkijat tõlkisid küsimustiku kas inglise keelest eesti keelde või inglise keelest vene keelde. Kahe tõlke ühisversioonid mõlemas keeles tõlkis professionaalne tõlkija tagasi inglise keelde. Seejärel võrreldi omavahel originaalküsimustikku ja tagasitõlkeid, et anda hinnang küsimuste sisulisele ühtelangevusele. Enne küsimustiku kasutuselevõttu katsetati seda ekspertide peal ja tehti prooviuuring. Ekspertideks valiti kahte keelt kõnelevad kinnipeetavad (kolm eesti keelt, kolm vene keelt ning kolm mõlemat keelt kõnelevat kinnipeetavat), et küsimustiku saaks kohandada võimalikult ekvivalentseks nii keeleliselt kui ka vangla subkultuuriliselt. Selle tulemusel kohandati küsimuste sõnastust nii eesti- kui ka venekeelses versioonis.

\section{Uuringu protseduur}

Pärast seda, kui ministeeriumist oli saadud luba uuringu korraldamiseks ühes Eesti kinnises meeste kambervanglas, tutvustati uuringut vangla juhtkonnale, kes andis selle korraldamiseks loa. Info uuringu kohta jõudis kõikide uuringu ajal kättesaadavate kinnipeetavateni kas vanglapersonali vahendusel kirjalikult eesti ja vene keeles või otseselt uurija suulise tutvustuse kaudu. Uuringus osalemine oli vabatahtlik ning osalenud täitsid küsimustiku individuaalselt või keskmiselt 3-4liikmelises väikeses grupis kinnipeetavate jaoks mittepersonaliseeritud vaikses ruumis, kus nende juures ei viibinud vanglapersonali. Enne ankeedi täitmist tutvustati uuritavatele uuringu eesmärke, anonüümsus- ja konfidentsiaalsusprintsiipi. Uuritavatele kinnitati, et esitatud küsimustele ei ole õigeid ega valesid vastuseid, vaid uurijaid huvitavad nende isiklikud hinnangud, arvamused ja ettepanekud.

Kinnipeetavad täitsid ankeedi oma vabal ajal ning ruumipaigutusega tagati, et neil ei olnud omavahelist pilkkontakti ja nad ei saanud näha 
üksteise vastuseid. Uurija viibis ruumis kogu anketeerimise ajal, andes vajaduse korral üleskerkinud küsimustele vastuseid ja abistades lugemis-/ kirjutamisraskuste korral.

Nii eesti- kui ka venekeelsel küsimustikul oli tiitelleht, mis sisaldas infot uuritavate anonüümsuse kohta, samuti oli seal kirjas, et ainult uurija näeb uuritavate individuaalseid vastuseid. Küsimustike täitmine võttis keskmiselt 45 minutit, varieerudes poolest tunnist kuni pooleteise tunnini. Pärast küsimustiku täitmist asetasid kinnipeetavad küsimustiku ümbrikusse, kleepisid selle kinni ja tõid uurija kätte. Rikutud või täitmata küsimustikke polnud ja kõik ankeedid kaasati andmetöötlusesse. Kõikidest kinnipeetavatest, kes olid uuringu ajal (kahe ja poole kuu vältel 2014. aasta lõpus) uurijale kõrge turvalisusastmega kinnipidamisasutuses kättesaadavad, vastas küsimustikule $32 \%$.

\section{Valim}

Uuringus osales kokku 110 meessoost kinnipeetavat, kes kandsid karistust ühes Eesti kinnises kambervanglas. Uuritavate vanus jäi vahemikku 22-66 aastat ja kinnipeetavate keskmine vanus oli 32,8 aastat $(S D=9,09)$. Kinnipeetavatest $69 \%$ olid eestlased, $27 \%$ venelased ja $4 \%$ muust rahvusest. Kantava karistusaja keskmiseks pikkuseks oli 33,7 kuud $(S D=35,41)$ ning kogu elu jooksul kinnipidamisasutuses viibitud aja pikkuseks oli 87,2 kuud $(S D=64,73)$. Toimepandud süütegudest olid sagedasimad varavastased süüteod $-43 \%$ juhtudest. Eluvastaseid ja teisi vägivallategusid oli korda saatnud 32\% kinnipeetavatest. 15\% kinnipeetavatest oli seotud uimasteid puudutavate süütegudega, $1 \%$ sooritanud seksuaalkuritegusid ja $9 \%$ muid (nt majandusalaseid) süütegusid.

\section{Tulemused}

Tulemused esitatakse alljärgnevalt mitmes osas. Kõigepealt tuuakse kasutatud mõõtevahendi psühhomeetrilised näitajad, seejärel keskendutakse vanglakiusamise olemuse ja ulatuse kirjeldamisele, lähtudes kahest aspektist: teiste kinnipeetavate kiusamine ja kiusamise ohvriks langemine. Järgmisena esitatakse kinnipeetavate jaotumine kategooriatesse, võttes arvesse nende seotust või mitteseotust vanglakiusamisega, ning sellele järgneb nende gruppide sisene paariviisiline võrdlus, mis põhineb kinnipeetavate personaalsetel (vanus, rahvus, süüteo liik, kinnipidamisasutuses viibitud aeg) ja käitumuslikel karakteristikutel (negatiivne, positiivne ja uimastitega seotud käitumine) ning reaktsioonidel kiusamisele. Andmeanalüüsiks 
kasutati kirjeldavat statistikat ning statistilistest olulisustestidest $F$-testi ja $\chi^{2}$-testi.

\section{DIPC-Ri faktoranalüïs ja sisereliaablus}

DIPC-Ri küsimustiku 111 küsimuse puhul, mis puudutasid kiusamis- ja ohvrikäitumist, tehti peakomponentide meetodi abil faktoranalüüs ning faktorite arvu määramiseks kasutati scree-plot-testi ja omaväärtust $>1$, arvestades faktorite sisulist interpreteeritavust. Sisuliselt kõige selgemalt interpreteeritavaks osutus kuuefaktoriline mudel, mis kirjeldas $66 \%$ koguhajuvusest. Kõik faktorlaadungid alates 0,38 st olid kuuel faktoril positiivsed ning laadusid ainult ühele faktorile, langedes kokku küsimustiku originaalis (Ireland, 2002a) kirjeldatud alaskaaladega, kusjuures otsese kiusamiskäitumise faktor kirjeldas $24 \%$, otsese ohvrikäitumise faktor $13 \%$, kaudse kiusamiskäitumise faktor $12 \%$, kaudse ohvrikäitumise faktor $9 \%$, sunniviisilise kiusamiskäitumise faktor $5 \%$ ja sunniviisilise ohvrikäitumise faktor $3 \%$ koguhajuvusest.

DIPC-Ri reliaabluse väljaselgitamiseks kasutati Cronbachi alfa koefitsienti. Kõikide skaalade sisemine reliaablus oli usaldusväärne (Cronbachi alfa vahemikus $0,83-0,91$; tabel 1 ).

Tabel 1. DIPC-Ri alaskaalade sisereliaablus

\begin{tabular}{|c|c|c|c|c|c|}
\hline \multirow[t]{2}{*}{ DIPC-Ri alaskaalad } & \multirow{2}{*}{$\begin{array}{c}\text { Küsimuste } \\
\text { arv }\end{array}$} & \multicolumn{2}{|c|}{ Cronbachi $a$} & \multicolumn{2}{|c|}{ Standardhälve } \\
\hline & & $\begin{array}{c}\text { Eesti- } \\
\text { keelne } \\
\text { versioon }\end{array}$ & $\begin{array}{c}\text { Vene- } \\
\text { keelne } \\
\text { versioon }\end{array}$ & $\begin{array}{c}\text { Eesti- } \\
\text { keelne } \\
\text { versioon }\end{array}$ & $\begin{array}{c}\text { Vene- } \\
\text { keelne } \\
\text { versioon }\end{array}$ \\
\hline Otsene kiusamiskäitumine & 33 & 0,85 & 0,87 & 2,08 & 2,10 \\
\hline Otsene ohvrikäitumine & 33 & 0,91 & 0,89 & 1,77 & 2,01 \\
\hline Kaudne kiusamiskäitumine & 13 & 0,91 & 0,90 & 2,32 & 1,99 \\
\hline Kaudne ohvrikäitumine & 14 & 0,84 & 0,86 & 2,01 & 2,11 \\
\hline Sunniviisiline kiusamiskäitumine & 9 & 0,85 & 0,83 & 2,54 & 2,53 \\
\hline Sunniviisiline ohvrikäitumine & 9 & 0,89 & 0,85 & 2,71 & 2,32 \\
\hline
\end{tabular}




\section{Kiusamis- ja ohvrikäitumise olemus ning ulatus vanglas}

DIPC-Ri instrumendiga mõõdetud uurimistulemused näitavad, mitu protsenti uuritavatest leiab, et nad puutusid eelmise nädala jooksul vähemalt korra kokku käitumisaktidega, mis kirjeldavad kas teiste kinnipeetavate kiusamist (kiusamiskäitumine) või kiusamise ohvriks langemist (ohvrikäitumine), ilma et sõna kiusamine oleks küsimustikus sisaldunud.

Uuringust selgus, et 57\% kõikidest uuritavatest oli kiusanud teisi vähemalt korra nädalas. Seejuures oli kaudse kiusamiskäitumisega seotud 39\%, sunniviisilise kiusamiskäitumisega $4 \%$ ning otsese kiusamiskäitumisega $24 \%$ uuritavatest. Otsese kiusamise liikidest olid kõik kiusaja staatuses olevad kinnipeetavad kasutanud verbaalset kiusamist, 18\% füüsilist, 16\% psühholoogilist ja 1\% vargustega seotud kiusamist.

63\% kõikidest kinnipeetavatest märkis, et oli vähemalt korra nädala jooksul langenud kiusamise ohvriks. Ohvrikäitumise liikidega seoses ilmnes, et 36\% kinnipeetavatest oli seotud kaudse, $8 \%$ sunniviisilise ja $19 \%$ otsese ohvrikäitumisega. Otsese ohvrikäitumise liikidest prevaleeris verbaalne kiusamine, mida olid kogenud kõik ohvri staatuses uuritavad. Sageduselt järgmisena olid uuritavad kogenud füüsilist kiusamist (17\%), millele järgnes psühholoogiline ja vargustega seotud ohvrikäitumine (mõlemad $11 \%$ juhtudest). Seksuaalse ohvrikäitumise kogemusega oli $4 \%$ kinnipeetavatest.

Uuringust ilmnes, et kaudne kiusamiskäitumine oli sagedasem kui otsene ja sunniviisiline kiusamiskäitumine (vastavalt $\chi^{2}=5,41, p<0,05$; $\left.\chi^{2}=39,1, p<0,00\right)$, kusjuures kiusajapoolset otsest agressiooni esines oluliselt sagedamini kui sunniviisilist $\left(\chi^{2}=17,02, p<0,00\right)$. Kaudse kiusamiskäitumise peamisteks viisideks olid tahtlik ignoreerimine ja tagaselja kritiseerimine. Ka ohvrikäitumisega seoses nähtus uuringust, et kaudne ohvrikäitumine oli otsese ja sunniviisilise käitumisega võrreldes sagedasem (vastavalt $\chi^{2}=5,27, p<0,05 ; \chi^{2}=20,04, p<0,01$ ), seejuures esines otsest ohvrikäitumist sagedamini kui sunniviisilist $\left(\chi^{2}=4,67, p<0,05\right)$. Kaudse ohvrikäitumise peamisteks viisideks olid tagarääkimine ja kuulujuttude levitamine. Seega kogesid uuritavad kiusamis- ja ohvrikäitumise liikidest kõige sagedamini verbaalset agressiooni, millele järgnes sageduselt psühholoogiline agressioon. Kõige harvem kogeti seksuaalset agressiooni. Vargustega seotud ohvrikäitumine oli oluliselt sagedasem kui vargustega seotud kiusamiskäitumine $\left(\chi^{2}=8,12, p<0,01\right)$. 


\section{Kiusamisega seotud kinnipeetavate gruppide liikmete personaalsete karakteristikute võrdlus}

Kinnipeetavad jaotati nelja kategooriasse, toetudes DIPC-Ri tulemustele: kiusaja/ohver $(43 \%, N=47)$, kiusaja $(14 \%, N=16)$, ohver $(20 \%, N=22)$ ja kiusamiskäitumisega mitteseotud kinnipeetavad $(23 \%, N=25)$. Tabelis 2 on toodud nendesse kategooriatesse kuuluvate kinnipeetavate personaalsed karakteristikud vanuse, rahvuse, kantava karistusaja pikkuse ja kogu elu kinnipidamisasutuses viibitud aja ning süüteo liigi kaupa.

Tabel 2. Kinnipeetavate personaalsete karakteristikute esinemissagedus uuritavate gruppide kaupa

\begin{tabular}{|c|c|c|c|c|}
\hline $\begin{array}{l}\text { Personaalsed } \\
\text { karakteristikud }\end{array}$ & $\begin{array}{l}\text { Kiusaja/ } \\
\text { ohver } \\
N=47\end{array}$ & $\begin{array}{l}\text { Kiusaja } \\
N=16\end{array}$ & $\begin{array}{l}\text { Ohver } \\
N=22\end{array}$ & $\begin{array}{c}\text { Kiusamis- } \\
\text { käitumisega } \\
\text { mitteseotud } \\
\text { kinnipeetavad } \\
N=25\end{array}$ \\
\hline Keskmine vanus aastates (SD) & $\begin{array}{c}30,9 \\
(S D=8,37)\end{array}$ & $\begin{array}{c}29,0 \\
(S D=5,90)\end{array}$ & $\begin{array}{c}36,5 \\
(S D=10,09)\end{array}$ & $\begin{array}{c}36,8 \\
(S D=9,02)\end{array}$ \\
\hline $\begin{array}{l}\text { Kantava karistusaja keskmine } \\
\text { pikkus kuudes }(S D)\end{array}$ & $\begin{array}{c}38,1 \\
(S D=39,17)\end{array}$ & $\begin{array}{c}27,5 \\
(S D=24,12)\end{array}$ & $\begin{array}{c}35,2 \\
(S D=34,03)\end{array}$ & $\begin{array}{c}25,5 \\
(S D=33,51)\end{array}$ \\
\hline $\begin{array}{l}\text { Kogu elu jooksul kinni- } \\
\text { pidamisasutuses viibitud aeg } \\
\text { kuudes }(S D)\end{array}$ & $\begin{array}{c}96,4 \\
(S D=69,54)\end{array}$ & $\begin{array}{c}59,8 \\
(S D=30,34)\end{array}$ & $\begin{array}{c}104,1 \\
(S D=65,57)\end{array}$ & $\begin{array}{c}63,9 \\
(S D=62,18)\end{array}$ \\
\hline \multicolumn{5}{|l|}{ Rahvus (\%) } \\
\hline Eestlane & 75 & 75 & 64 & 60 \\
\hline Venelane & 23 & 25 & 31 & 32 \\
\hline Muu rahvus & 2 & 0 & 5 & 8 \\
\hline \multicolumn{5}{|l|}{ Süüteod (kattuvad \%) } \\
\hline $\begin{array}{l}\text { Eluvastased süüteod ja teised } \\
\text { vägivallateod }\end{array}$ & 33 & 30 & 31 & 33 \\
\hline Varavastased süüteod & 45 & 44 & 39 & 41 \\
\hline Uimastitega seotud süüteod & 12 & 17 & 12 & 22 \\
\hline Seksuaalkuriteod & 1 & 0 & 4 & 0 \\
\hline Muud süüteod & 9 & 9 & 15 & 4 \\
\hline
\end{tabular}


Olulised erinevused kinnipeetavate gruppide vahel ilmnesid seoses kinnipeetavate vanusega. Nimelt olid kiusajad/ohvrid ja kiusajad üldjuhul nooremad kui ohvrid ja kiusamiskäitumisega mitteseotud kinnipeetavad. Statistiliselt olulised erinevused kõnealuste gruppide vahel olid järgmised: kiusajad/ohvrid $v$ s. ohvrid, $F=2,15, p<0,05$; kiusajad/ohvrid $v s$. kiusamiskäitumisega mitteseotud kinnipeetavad, $F=2,20, p<0,05$; kiusajad $v$. ohvrid, $F=2,62, p<0,01$; kiusajad $v s$. kiusamisega mitteseotud kinnipeetavad, $F=2,32, p<0,05$.

Oluliseks erinevuseks nelja uuritud grupi võrdluses osutus ka kantava karistusaja pikkus, samuti see, et kiusajad/ohvrid ja ohvrid olid kinnipidamisasutuses viibinud märkimisväärselt kauem kui kiusajad ja kiusamiskäitumisega mitteseotud grupi liikmed. Olulised erinevused uuritavate gruppide vahel olid järgmised: kiusajad/ohvrid $v$ s. kiusajad, $F=2,52$, $p<0,05$; kiusajad/ohvrid vs. kiusamiskäitumisega mitteseotud kinnipeetavad, $F=2,34, p<0,05$; kiusajad vs. ohvrid, $F=2,51, p<0,05$; ohvrid $v s$. kiusamiskäitumisega mitteseotud kinnipeetavad, $F=2,03, p<0,05$.

Veel üheks erinevuseks uuritavate gruppide vahel olid eelnevaga sarnased tendentsid, mis on seotud kogu elu kinnipidamisasutuses viibitud ajaga. Ilmnes, et aeg, mille on kiusajate/ohvrite ja ohvrite grupi liikmed veetnud oma elu jooksul kinnipidamisasutuses, oli pikem võrreldes ülejäänud gruppide liikmete omaga. Olulised erinevused gruppide vahel olid järgmised: kiusajad/ohvrid vs. kiusajad, $F=3,03, p<0,00$; kiusajad/ohvrid $v s$. kiusamiskäitumisega mitteseotud kinnipeetavad, $F=2,13, p<0,05$; kiusajad $v s$. ohvrid, $F=2,91, p<0,01$; ohvrid $v s$. kiusamiskäitumisega mitteseotud kinnipeetavad, $F=2,24, p<0,05$.

Rahvuse ja süüteo liigi puhul kiusajate/ohvrite, kiusajate, ohvrite ja kiusamiskäitumisega mitteseotute gruppide liikmete vahel statistiliselt olulisi erinevusi ei ilmnenud.

\section{Kiusamisega seotud kinnipeetavate gruppide liikmete käitumuslike karakteristikute võrdlus}

Kiusajate/ohvrite, kiusajate, ohvrite ja kiusamiskäitumisega mitteseotud kinnipeetavate käitumuslikke karakteristikuid uuriti kolmest aspektist: negatiivne ja positiivne käitumine kinnipidamisasutuses ning uimastitega seotud käitumine. Uurimistulemuste põhjal arvutati nende kinnipeetavate protsent, kellel ilmnes nädala jooksul vähemalt üks positiivne, negatiivne või uimastitega seotud käitumisakt (tabel 3). 
Tabel 3. Positiivse, negatiivse või uimastitega seotud käitumisega kokku puutunud kinnipeetavate protsent uuritavate gruppide kaupa

\begin{tabular}{l|c|c|c|c}
\hline Kinnipeetavate käitumine & $\begin{array}{c}\text { Kiusaja/ohver } \\
N=47\end{array}$ & $\begin{array}{c}\text { Kiusaja } \\
N=16\end{array}$ & $\begin{array}{c}\text { Ohver } \\
N=22\end{array}$ & $\begin{array}{c}\text { Kiusamiskäitu- } \\
\text { misega mitteseotud } \\
\text { kinnipeetavad } \\
N=25\end{array}$ \\
\hline Negatiivne käitumine & 51,1 & 37,5 & 36,6 & 20 \\
\hline Positiivne käitumine & 63,8 & 62,5 & 54,5 & 20 \\
\hline Uimastitega seotud käitumine & 46,8 & 37,5 & 31,8 & 36 \\
\hline
\end{tabular}

Negatiivse käitumisega paistsid enim silma kiusajate/ohvrite gruppi kuulujad, seejuures ilmnesid olulised erinevused kiusajate/ohvrite ja kiusamiskäitumisega mitteseotud gruppide vahel $\left(\chi^{2}=5,32, p<0,05\right)$. Konkreetsed küsimused, mille põhjal eelnimetatud tendents avaldus, puudutasid negatiivset käitumist vanglapersonali suhtes (nt „Olen keeldunud personaliliikme käsku täitmast”, „Personaliliige on minu peale karjunud”, „Olen solvanud personaliliiget").

Uuringust nähtus, et kiusamisega seotud gruppide (kiusaja/ohvri, kiusaja, ohvri) liikmetel esines sagedamini positiivset käitumist võrreldes kiusamisega mitteseotud kinnipeetavatega: kiusamiskäitumisega mitteseotud kinnipeetavad $v$ s. kiusajad/ohvrid, $\chi^{2}=10,86, p<0,00$; kiusamiskäitumisega mitteseotud kinnipeetavad vs. kiusajad, $\chi^{2}=5,87, p<0,05$; kiusamiskäitumisega mitteseotud kinnipeetavad $v s$. ohvrid, $\chi^{2}=4,65$, $p<0,05$. Need ankeedi küsimused, mis iseloomustasid kiusamisega seotud gruppidesse kuulujaid, hõlmasid positiivset käitumist teiste kinnipeetavate suhtes (nt „Olen vahele astunud ja kakluse peatanud”, „Olen aidanud uuel kinnipeetaval kohaneda”, „Olen püüdnud aidata kellelgi ta probleeme lahendada"). Uimastitega seotud käitumises nelja uuritava grupi vahel statistiliselt olulisi erinevusi ei leitud.

\section{Kiusamisega seotud kinnipeetavate gruppide liikmete reaktsioonid kiusamisele}

Tabelis 4 on esitatud kiusajate/ohvrite, kiusajate ja ohvrite reaktsioonide esinemissagedused nädala jooksul seoses kiusamisega, tuginedes DIPC-Ri küsimustikule. 
Tabel 4. Vanglakiusamisega seotud reaktsioonide sagedus protsentides kiusamist kogenud kinnipeetavate gruppide kaupa, $\chi^{2}$ väärtused ja olulisuse määrad

\begin{tabular}{|c|c|c|c|c|c|c|}
\hline \multirow[t]{2}{*}{ Reaktsioonid kiusamisele } & \multirow{2}{*}{$\begin{array}{c}\text { Kiusaja/ } \\
\text { ohver } \\
N=47 \\
\text { (A) }\end{array}$} & \multirow{2}{*}{$\begin{array}{c}\text { Kiusaja } \\
N=16 \\
\text { (B) }\end{array}$} & \multirow{2}{*}{$\begin{array}{c}\text { Ohver } \\
N=22 \\
\text { (C) }\end{array}$} & \multicolumn{3}{|c|}{$\chi^{2}$ väärtus } \\
\hline & & & & $\begin{array}{c}\text { A } \\
v s . \\
B\end{array}$ & $\begin{array}{c}\text { A } \\
\text { vs. } \\
\text { C }\end{array}$ & $\begin{array}{c}\text { B } \\
v s . \\
\text { C }\end{array}$ \\
\hline Nutmine & $28 \%$ & $0 \%$ & $64 \%$ & $4,02^{*}$ & $6,70^{* *}$ & $13,50^{* *}$ \\
\hline Oma kambrisse jäämine & $6 \%$ & $0 \%$ & $5 \%$ & ns & ns & ns \\
\hline $\begin{array}{l}\text { Soov kolida või kolimine teise } \\
\text { kohta }\end{array}$ & $17 \%$ & $7 \%$ & $14 \%$ & ns & ns & ns \\
\hline Enesevigastused & $8 \%$ & $0 \%$ & $5 \%$ & ns & ns & ns \\
\hline Ähvardamine enesevigastustega & $8 \%$ & $7 \%$ & $5 \%$ & ns & ns & ns \\
\hline Teise kinnipeetava löömine & $17 \%$ & $7 \%$ & $0 \%$ & $4,90^{*}$ & $7,64^{* *}$ & ns \\
\hline Kiusamise lõpetamine & $38 \%$ & $0 \%$ & $36 \%$ & $5,81^{*}$ & ns & $5,34^{*}$ \\
\hline Enda kaitsmine & $47 \%$ & $6 \%$ & $41 \%$ & $4,04^{*}$ & ns & $3,97^{*}$ \\
\hline $\begin{array}{l}\text { Teisele kinnipeetavale kiusamisest } \\
\text { rääkimine }\end{array}$ & $26 \%$ & $0 \%$ & $32 \%$ & $4,07^{*}$ & ns & $4,94^{*}$ \\
\hline $\begin{array}{l}\text { Personaliliikmele kiusamisest rää- } \\
\text { kimine }\end{array}$ & $13 \%$ & $0 \%$ & $0 \%$ & $5,35^{*}$ & $5,38^{*}$ & ns \\
\hline
\end{tabular}

Märkus. ${ }^{*}-p<0,05 ;{ }^{* *}-p<0,01$.

Uuringust ilmnesid mitmed olulised erinevused uuritavate gruppide reaktsioonides kiusamisele. Nimelt olid kiusajate/ohvrite ja ohvrite reaktsioonid võrreldes kiusajate omadega sagedamini seotud kiusamise lõpetamisele suunatud tegevusega, enese kaitsmisega või kiusamisest teisele kinnipeetavale rääkimisega. Uuringust nähtus samuti, et sagedasimaks reaktsiooniks kiusamisele oli ohvritel nutmine, kusjuures nutmine oli sageduselt järgmisena omane ka kiusajate/ohvrite grupi liikmetele, kuid mitteomane kiusajatele. Statistiliselt olulisi erinevusi vältivate reaktsioonide või enesevigastusi puudutavate reaktsioonide korral kolme uuritava grupi liikmete vahel ei ilmnenud.

\section{Arutelu}

Vanglakiusamise uurimine on Eestis alles algusjärgus (nt Kõiv \& Maasikas, 2014), mistõttu ei võimalda ka praegune kvantitatiivne kirjeldav-võrdlev uuring teha laialdasi üldistusi. Küll aga saab Eestis tehtud uuringu tulemusi 
kõrvutada teistes riikides tehtud samateemaliste uuringute omadega, et osutada põhitendentsidele.

Siinses artiklis ei otsitud vastust küsimusele miks?, vaid esimeseks võtmeküsimuseks oli, mil määral ja kelle hulgas esineb otsest, kaudset ja sunniviisilist kiusamist ühes Eesti meestevanglas tehtud uuringu põhjal. Uurimistulemused näitavad, et kiusamine on vaatlusaluses vanglas laialdane probleem, sest üle poole uuritavatest oli nädala jooksul teisi kiusanud (57\%) või langenud kiusamise ohvriks (63\%).

Vanglakiusamise olemuse uurimine kahest aspektist - teiste kinnipeetavate kiusamine (kiusamiskäitumine) ja kiusamise ohvriks langemine (ohvrikäitumine) - võimaldab prevaleerivate kiusamisliikide põhjal välja tuua järgmised tendentsid. Esiteks, kaudse kiusamise ülekaal (ligikaudu $40 \%$ kiusamiskäitumise ja 25\% ohvrikäitumise korral vs. ligikaudu 20\% otsese kiusamis- ja ohvrikäitumise korral) viitab varasemates uurimustes ilmnenud samasugustele tendentsidele täiskasvanud kinnipeetavate seas (Archer et al., 2014; Ireland, 1999a; Ireland et al., 2007; Ireland \& Power, 2004), st kaudne kiusamine on prevaleeriv kiusamisliik vanglas. Samal ajal osutus sunniviisilise kiusamis- ja ohvrikäitumise ulatus praeguse valimi puhul väikseimaks, kui kõrvutada seda kaudse ja otsese kiusamise määradega, jäädes vastavalt $4 \%$ ja $8 \%$ piirimaile, mis viitab varasematele samalaadsetele tendentsidele (Ireland, 2005a). Kaudse kiusamise suurt esinemissagedust põhjendatakse sellega, et seda liiki kiusamist on vanglapersonalil raske märgata, mis vähendab tõenäosust saada karistatud (Ireland, 2005a; Ireland et al., 2007). Samas on kaudsel kiusamisel samavõrd tõsised negatiivsed tagajärjed kui näost näkku toimuval otsesel kiusamisel (Ireland, 2000). Seetõttu ei saa vanglakiusamise puhul piirduda üksnes vanglapoolse dokumenteeritud statistikaga kiusamisjuhtude kohta, vaid intervjuude või enesekohaste meetodite abil on vaja uurida ka vanglakiusamise varjatud liike. Ainult nii saab võidelda kiusamisega võimalikult tõhusalt, mida on näidanud tõenduspõhised sekkumised (nt Smith, Pendleton, \& Mitchell, 2005).

Teiseks, analüüsides otsese kiusamis- ja ohvrikäitumise liikide esinemust uuritavate meeskinnipeetavate seas, ilmnes, et ülekaalukaim oli verbaalne kiusamine (24\% juhtudest) ning sellele järgnes füüsiline (18\% kiusamiskäitumise ja 17\% ohvrikäitumise korral) ja psühholoogiline kiusamine (16\% kiusamiskäitumise ja $11 \%$ ohvrikäitumise korral), harvim oli seksuaalne kiusamine. Verbaalse kiusamise laiaulatuslikkust otsese vanglakiusamise liikide seas on täheldatud ka varem (Kõiv \& Maasikas, 2014), seejuures on selle olemusliku tunnusena leitud, et verbaalset agressiooni rakendavat kiusajat ja/või kogevat ohvrit on raske vanglas identifitseerida (Ireland 
\& Ireland, 2000). Füüsiline kiusamis- ja ohvrikäitumine on osutunud varasemate uurimuste (Ireland, 1999a; Ireland \& Power, 2004, 2013; Ireland \& Rowley, 2007) põhjal mõnevõrra vähem ulatuslikuks, viidates erinevustele vanglakiusamise liikide strukturaalses esinemissageduses.

Vargustega seotud ohvrikäitumist esines praeguse valimi puhul oluliselt sagedamini (11\%) kui vargustega seotud kiusamiskäitumist (1\%). Sama tendents on ilmnenud ka varasematest uurimustest (Brewer, 2010; Ireland, 1999a). Asjaolu, et vargustega seotud ohvrikäitumise kogemus oli olemas oluliselt suuremal hulgal kinnipeetavatest võrreldes sama tüüpi kiusamiskäitumise kogemusega, võib viidata sellele, et vargusega seotud kiusamisvorme rakendab vaid väike hulk kiusajaid, kuid nende ohvrite hulk on suhteliselt laialdane. Teisalt on ohvrikäitumise ulatusega kaasnev probleem terav ka sellele tõttu, et ohvri staatus vanglas on nõrkuse märk ja see pole sotsiaalselt aktsepteeritud, mis suurendab võimalust, et ohvriks langemise ulatust alahinnatakse (Ireland \& Archer, 1996).

Kuna kiusamis- ja ohvrikäitumine võivad kattuda, siis vanglakäitumise üldisest ulatusest vaatlusaluse valimi puhul annab selgema pildi kinnipeetavate jagamine nelja gruppi: kiusajad, ohvrid, kiusajad/ohvrid ja kiusamisega mitteseotud kinnipeetavad. Uurimusest ilmnes, et 77\% meessoost kinnipeetavatest oli seotud vanglakiusamisega kas kiusaja või ohvrina. Nimelt oli 43\% kinnipeetavatest nädala jooksul teisi kiusanud ja samal ajal langenud ka teiste kinnipeetavate poolse kiusamise ohvriks (kiusajad/ohvrid), 22\% oli langenud kiusamise ohvriks ning üle 14\% oli kiusanud teisi kinnipeetavaid. Alla 23\% kinnipeetavatest polnud nädala jooksul seotud vanglakiusamisega ei kiusaja ega ohvrina.

Nelja kinnipeetavate grupi proportsionaalne jaotus langeb kokku varem täiskasvanud meeste uurimisel saadud tulemustega, kus domineerib kiusajate/ohvrite grupp (nt Brewer, 2010; Ireland \& Power, 2013; Palmer \& Thakordas, 2005; Wood et al., 2009). Kiusajate/ohvrite prevaleerimist teiste vanglakiusamisega seotud gruppide seas on põhjendatud sellega, et kiusajad/ohvrid võivad kasutada agressiooni teiste kinnipeetavate vastu eesmärgiga domineerida ja vältida ohvriks langemist (Connell \& Farrington, 1996). Lisaks on täheldatud, et kui kiusajad/ohvrid kasutavad teiste kiusamist pigem oma kõrgema positsiooni saavutamiseks, siis kiusajad soovivad sel viisil säilitada oma sotsiaalset positsiooni teiste kinnipeetavate seas (South \& Wood, 2006). Teisalt, varasematest uurimustest ilmneb, et kiusamisega mitteseotud meeskinnipeetavate esinemus jääb veerandi piirimaile (nt Ireland, 2002c: 38\%; Ireland \& Ireland, 2000: 31\%; Ireland \& Power, 2004: 42\%; Ireland \& Qualter, 2008: 46\%; Palmer \& Thakordas, 2005: $29 \%)$, kusjuures ka praeguses valimis oli see ligikaudu veerand. Nii nagu 
koolikontekstis leiab kiusamine aset siis, kui kõrvalseisjad selle toimumist võimaldavad (Twemlow \& Sacco, 2008), toimub ka vanglakiusamine kaaslaste grupis (Ireland, 2011), mistõttu on oluline kaasata kõrvalseisjaid kiusamisvastasesse võitlusesse.

Teine võtmeküsimus, millele otsiti uurimuses vastust, oli järgmine: kas nendel kinnipeetavatel, kes on vaatlusaluses vanglas kogenud kiusamist kiusaja ja/või ohvri rollis või pole kiusamist kogenud, on erinevad personaalsed ja käitumuslikud karakteristikud ning reaktsioonid kiusamisele? Sisuliselt puudutab see küsimus ühte faktorigruppi - kinnipeetavate personaal-demograafilisi (personaalseid, käitumuslikke, reageerimisega seotud) karakteristikuid -, mis koosmõjus kinnipeetavate sisemiste psühholoogiliste tunnusjoontega (nt sotsiaalne enesehinnang (Ireland, 2002d), kiindumusstiil ja sotsiaalne üksindus (Ireland \& Power, 2004), isiksuslikud jooned (Turner \& Ireland, 2010)) ning kinnipidamisasutuse sotsiaalsete ja füüsiliste tunnusjoontega (nt vangla subkultuur, tiheliolek ja vähene stimulatsioon) võivad vanglakiusamist esile kutsuda, säilitada või õhutada.

Kahtluse alla on seatud, kas kinnipeetavate personaalsed karakteristikud, nagu vanus, rahvus, süüteo liik ja kinnipidamisasutuses viibitud aeg, eristavad kiusamisega seotud kinnipeetavate gruppe (Ireland, 2005a). On leitud, et grupikuuluvuse määrab pigem isiku käitumine vanglas viibimise ajal või tema sisemised psühholoogilised karakteristikud (Ireland \& Ireland, 2000). Nii nagu varasematest uurimustest (Ireland, 1999a; Leddy \& O'Connell, 2002; South \& Wood, 2006), ilmnes ka praegusel juhul, et vanglakiusamise ohvrid ja kiusamiskäitumisega mitteseotud kinnipeetavad olid enamasti vanemaealisemad kui kiusajate ja kiusajate/ohvrite grupi liikmed. See võib peegeldada tendentsi, et kiusamiskäitumine eelneb arengulisest perspektiivist noorukite kuritegelikule käitumisele (Baldry \& Farrington, 2000).

Ka pikim vangistusaeg (praegu ja kogu elu kinnipidamisasutuses viibitud aeg) eristas kiusajaid/ohvreid kiusamisega mitteseotud kinnipeetavate grupist, ühtides varasemate tulemustega (Ireland, 1999a, 2001; Ireland et al., 2007; Ireland \& Rowley, 2007; South \& Wood, 2006). Lisaks ilmnes, et praegusesse valimisse kuulunud ohvritel oli pikem vangistusaeg (praegu ja kogu elu kinnipidamisasutuses viibitud aeg) võrreldes kiusajate ja kiusamisega mitteseotud kinnipeetavate grupiga. See uurimistulemus vastandub varem leitule (Tahir, 2011), andes alust spekulatsioonile, kuivõrd on see seotud eri maade õigusruumide erinevusega. Seevastu kaks personaalset karakteristikut - rahvus ja süüteo liik - ei ennustanud kuulumist või mittekuulumist mõnda vanglakiusamisega seotud uuritavate gruppi. Samale tendentsile on osutanud ka varasemad uurimused (Ireland, 2001; Palmer \& Thakordas, 2005; South \& Wood, 2006). 
Püsivaim käitumuslik karakteristik, mis eristab kiusajate/ohvrite gruppi teistest gruppidest, on negatiivne käitumine vanglapersonali ja -reeglite suhtes (Archer et al., 2014; Ireland, 1999a, 2001; Ireland et al., 2007; Ireland \& Rowley, 2007; South \& Wood, 2006). Ka praeguste uurimistulemuste põhjal ilmnes eelmainitud tendents kiusajate/ohvrite ja kiusamiskäitumisega mitteseotud kinnipeetavate võrdluses, viidates kinnipeetavate agressiivsele käitumisele vanglapersonali suhtes, mis on nähtunud ka varasematest uurimustest (Ireland, 2001). Praegused uurimistulemused näitavad, et positiivne käitumine - eelkõige teiste kinnipeetavate suhtes - on sagedasem kõikidel kiusamisega seotud kinnipeetavate gruppidel (kiusajad, ohvrid, kiusajad/ohvrid) kui kiusamisega mitteseotutel. Sellele osutavad ka varasemad uurimused (Ireland \& Rowley, 2007).

Irelandi ja tema kolleegide (2007) uurimus osutab, et kiusamisega mitteseotud kinnipeetavatel ilmneb suhteliselt harva positiivset ja negatiivset käitumist vanglas. On arvatud (ibid.), et negatiivse käitumisega püüavad kiusajad/ohvrid tõsta oma staatust ning selline käitumine on adaptiivne reaktsioon, et vältida vanglakiusamise märklauaks olemist. Küsimusi tekitab aga see, miks kalduvad kiusamisega mitteseotud kinnipeetavad jääma nii vanglakäitumise negatiivse kui ka positiivse kvaliteedi väljendamisel suhteliselt vaoshoituks. Võimalik, et selline käitumine on teatud rühma uuritavate puhul adaptiivne viis jääda vanglas kiusamise suhtes resistentseks.

Niisamuti selgus praeguste uurimistulemuste põhjal, et uuritud kinnipeetavate uimastikäitumise ulatus oli väike. See peegeldab nähtavasti vangla formaalsete reeglite rangust, mis võib seletada erinevusi, millele osutatakse varasemates uurimustes (Ireland, 2001; Ireland et al., 2007; Archer et al., 2014).

Meessoost kinnipeetavate reaktsioonid kiusamisele olid praeguse uurimuse põhjal eelkõige vältivat laadi. Kuna reaktsioonid kiusamisele on vangla füüsilise keskkonna tõttu piiratud, on vahetud reaktsioonid tõenäosemad (nt Ireland \& Snowden, 2002). Uurimistulemuste põhjal eristusid ohvri staatuses olevad kinnipeetavad (kiusaja/ohver, ohver) kiusajatest selle poolest, et nad täheldasid sagedamini vahetuid reaktsioone - enesekaitset ja aktiivseid toimetulekuviise kiusamise lõpetamiseks - ning kiusajad kasutasid sagedamini vastuagressiooni, millele viitavad ka varasemad leiud (Ireland, 1999a, 2001; Ireland \& Rowley, 2007). Emotsionaalne reaktsioon (nutmine) oli omane eelkõige ohvritele, seostudes varasemate samalaadsete leidudega (Archer et al., 2014), ning enesevigastused kui reaktsioon kiusamisele ilmnes suhteliselt harva, eristamata uuritavaid gruppe.

Vanglakiusamise varjatud iseloom, sh soov mitte informeerida vanglapersonali, on praeguste uurimistulemuste põhjal iseloomulik eelkõige 
ohvri (kiusaja/ohvri, ohvri) saatuses olevatele kinnipeetavatele. See võib tuleneda vangla subkultuuri koodist, mis hõlmab nõuet jääda lojaalseks teistele kinnipeetavatele ja mitte avaldada informatsiooni vanglapersonalile (Ireland, 2002b). Kinnipeetavate suhted vanglas toetuvad domineerimisele ja võimule ning vangla subkultuuriline reeglistik ei soosi kaebamist või informeerimist (ohvriks langemise korral personali informeerimist), mis iseenesest õigustab kiusamist vanglas (Connell \& Farrington, 1996; Ireland \& Archer, 1996). Teisalt ilmnes, et kiusajad/ohvrid, kuid mitte ülejäänud uuritavad räägivad vanglapersonalile sellest, et teised kinnipeetavad kiusavad neid. Sama tendents on nähtunud ka varasematest uurimustest (Ireland \& Rowley, 2007). Seejuures on välja toodud, et kinnipeetavad, kes kalduvad oma kiusamisest personalile rääkima, võivad tajuda suuremat ohtu langeda kaaslaste kiusamise ohvriks kui need, kes oma kiusamisest vaikivad (Wolff, Shi, \& Bachman, 2008). Vanglakiusamise ennetus- ja sekkumistegevuse planeerimise seisukohast on tähtis selgitada välja, kuidas kinnipeetavad, kes kannatavad kiusamise all ja/või kiusavad oma kaaslasi, reageerivad kiusamisele, sest see võimaldab kavandada tegevusi, mis toovad vanglakiusamise varjatud käitumisaktid avalikuks (Ireland, 2011).

Seega ilmneb eeltoodust, et kinnipeetavate personaal-demograafilistest karakteristikutest (personaalsed, käitumuslikud karakteristikud, reaktsioonid kiusamisele), mis koosmõjus teiste faktoritega võivad esile kutsuda, säilitada ja õhutada vanglakiusamist, näib olevat kõige ebajärjekindlam uuritud karakteristik kinnipeetavate reaktsioon vanglakiusamisele. See osutab vajadusele vaadelda kiusamisega seotud gruppide liikmete reaktsioone kiusamisele dünaamilisena, kasutades selleks pikiuuringuid. Uuritud nelja personaalse ja kolme käitumusliku karakteristiku seast eristasid suhteliselt järjekindlalt kinnipeetavate vanus ja kinnipidamisaja pikkus ning kinnipeetavate positiivne ja negatiivne käitumine vanglas kiusamisega mitteseotud kinnipeetavaid nendest kinnipeetavatest, kes olid ise kiusamise ohvrid ja samal ajal kiusasid teisi, mis viitab vaatlusalustele vanglakiusamisega seotud riskiteguritele.

Vanglakiusamist käsitlevad uurimused on liikunud kiusamise olemuse ja ulatuse uurimise juurest ühe laialdasema temaatika juurde, vaadeldes indiviidi ja kinnise institutsionaalse keskkonna vastastikmõju, mida seletab väljatoodud teoreetiline mudel (Ireland, 2011). Eestis on vanglakiusamise uurimine alles algusjärgus, omades potentsiaali arenguks, sest valiidsed mõõtevahendid (adapteeritud küsimustik DIPC-R ja varem adapteeritud küsimustik, vt Kõiv \& Maasikas, 2014), mis võimaldavad uurida vanglakiusamise kui sotsiaalse fenomeni mitmekülgset olemust, annavad selleks hea metoodilise lähtekoha. Teisalt, tundes vanglakiusamise olemust ja 
eristades seda vanglavägivallast, saab kavandada vanglakiusamisvastast võitlust laiaulatuslike strateegiatena mitmel tasandil (kinnipeetavad ja personal). See võimaldab suurendada asjaosaliste teadlikkust kiusamise olemusest ja liikidest ning kujundada kiusamisvastaseid hoiakuid, integreerides eri teenuseid, mis on seotud üleminekuga hariduse (üldhariduse, kutseõppe, tööelu) ja sotsiaalhoolekande vallas.

\section{Kasutatud kirjandus}

Allison, M. D., \& Ireland, J. L. (2010). Staff and prisoner perceptions of physical and social environmental factors thought to be supportive of bullying: The role of bullying and fear of bullying. International Journal of Law and Psychiatry, 33(1), 43-51. doi: http://dx.doi.org/10.1016/j.ijlp.2009.10.002

Archer, J., Ireland, J. L., \& Power, C. L. (2007). Differences between bullies and victims, and men and women, on aggression-related variables among prisoners. British Journal of Social Psychology, 46(2), 299-322.

doi: http://dx.doi.org/10.1348/014466606X114083

Archer, J., Ireland, J. L., \& Power, C. L. (2014). An investigation of the characteristics of adult prisoners involved in bullying. Research report. University of Central Lancashire.

Archer, J., \& Southall, N. (2009). Does cost-benefit analysis or self-control predict involvement in bullying behavior by male prisoners? Aggressive Behavior, 35(1), 31-40. doi: http://dx.doi.org/10.1002/ab.20283

Baldry, A. C., \& Farrington, D. P. (2000). Bullies and delinquents: Personal characteristics and parental styles. Journal of Community and Applied Social Psychology, 10(1), 17-31. doi. http://dx.doi.org/10.1002/(SICI)1099-1298(200001/02)10:1< 17::AID-CASP526>3.0.CO;2-M

Beck, G. (1994). Self-reported bullying among Scottish young offenders. Inside Psychology, 2, 16-21.

Blaauw, E. (2005). Bullying and suicides in prisons. In J. K. Ireland (Ed.), Bullying among prisoners: Innovations in theory and research (pp. 44-61). Hove: Willan.

Brewer, G. (2010). Psychological health and bullying among adult male offenders. International Journal of Prisoner Health, 6(1), 33-40.

Connell, A., \& Farrington, D. P. (1996). Bullying among incarcerated young offenders: Developing an interview schedule and some preliminary results. Journal of Adolescence, 19(1), 75-93. doi: http://dx.doi.org/10.1006/jado.1996.0007

Cornell, D. G., \& Brockenbrough, K. (2004). Identification of bullies and victims: A comparison of methods. Journal of School Violence, 3(2-3), 63-87. doi. http://dx.doi.org/10.1300/J202v03n02_05

Dyson, G. (2005). Examining bullying among institutionalized young offenders: Triangulation of questionnaires and focus groups. In J. L. Ireland (Ed.), Bullying among prisoners: Innovations in theory and research (pp. 84-108). Hove: Willan.

Edgar, K., O'Donnell, I., \& Marti, C. (2011). Prison violence: The dynamics of conflict, fear and power (2nd ed.). London, New York: Routlege. 
Farrington, D. P. (1993). Understanding and preventing bullying. In M. Tonry (Ed.), Crime and justice: A review of research, 17 (pp. 381-458). Chicago: University of Chicago Press. doi: http://dx.doi.org/10.1086/449217

Grennan, S., \& Woodhams, J. (2007). The impact of bullying and coping strategies on the psychological distress of young offenders. Psychology, Crime and Law, 13(5), 487-504. doi: http://dx.doi.org/10.1080/10683160601060598

Holland, D., Ireland, J. L., \& Muncer, S. (2009). Impulsivity, attribution and prison bullying: Bully-category and perpetrator-victim mutuality. International Journal of Law and Psychiatry, 32(2), 84-91. doi: http://dx.doi.org/10.1016/j.ijlp.2009.01.004

Ireland, J. L. (1999a). Bullying behaviors among male and female prisoners: A study of adult and young offenders. Aggressive Behavior, 25(3), 161-178.

Ireland, J. L. (1999b). Provictim attitudes and empathy in relation to bullying behaviour among prisoners. Legal and Criminological Psychology, 4(1), 51-66. doi: http://dx.doi.org/10.1348/135532599167789

Ireland, J. L. (2000). "Bullying" among prisoners: A review of research. Aggression and Violent Behavior, 5(2), 201-215. doi: http://dx.doi.org/10.1016/S1359-1789(98)00031-7

Ireland, J. L. (2001). Distinguishing the perpetrators and victims of bullying behaviour in a prison environment: A study of male and female adult prisoners. Legal and Criminological Psychology, 6(2), 229-246. doi: http://dx.doi.org/10.1348/135532501168307

Ireland, J. L. (2002a). The Direct and Indirect Prisoner Behaviour Checklist - Revised. Preston: University of Central Lancashire.

Ireland, J. L. (2002b). Bullying among prisoners: Evidence, research and intervention strategies. Hove, New York: Brunner-Routledge.

Ireland, J. L. (2002c). How does assertiveness relate to bullying behaviour among prisoners? Legal and Criminological Psychology, 7(4), 87-100. doi: http://dx.doi.org/10.1348/135532502168405

Ireland, J. L. (2002d). Social self-esteem and self-reported bullying behaviour among adult prisoners. Aggressive Behavior, 28(3), 184-197. doi: http://dx.doi.org/10.1002/ab.90021

Ireland, J. L. (2005a). Bullying among prisoners: The need for innovation. In J. L. Ireland (Ed.), Bullying among prisoners: Innovations in theory and research (pp. 3-23). Hove: Willan.

Ireland, J. K. (2005b). Psychological health and bullying behavior among adolescent prisoners: A study of young and juvenile offenders. Journal of Adolescent Health, 36(3), 236-243. doi: http://dx.doi.org/10.1016/j.jadohealth.2004.02.026

Ireland, J. L. (2011). Bullying in prisons: Bringing research up to date. In C. P. Monks \& I. Coyne (Eds.), Bullying in different contexts (pp. 137-156). Cambridge: Cambridge University Press. doi: http://dx.doi.org/10.1017/CBO9780511921018.007

Ireland, J. L., \& Archer, J. (1996). Descriptive analysis of bullying in male and female adult prisoners. Journal of Community \& Applied Social Psychology, 6(1), 35-47. doi: http://dx.doi.org/10.1002/(SICI)1099-1298(199602)6:1<35::AID-CASP353> 3.0.CO;2-U

Ireland, J. L., Archer, J., \& Power, C. L. (2007). Characteristics of male and female prisoners involved in bullying behavior. Aggressive Behavior, 33(3), 220-229. doi: http://dx.doi.org/10.1002/ab.20182 
Ireland, J. L., \& Bescoby N. (2005). Behavioral assessment of bullying behaviour among personality disordered patients in a high secure hospital. Aggressive Behavior, 31(1), 67-83. doi: http://dx.doi.org/10.1002/ab.20073

Ireland, J. L., \& Hill, C. (2001). Anti-bullying focus groups with prisoners. Prison Service Journal, 133, 40-42.

Ireland, J. L., \& Ireland, C. L. (2000). Descriptive analysis of the nature and extent of bullying behavior in a maximum-security prison. Aggressive Behavior, 26(3), 213223. doi: http://dx.doi.org/10.1002/(SICI)1098-2337(2000)26:3<213::AID-AB1> 3.0.CO;2-Z

Ireland, J. L., \& Ireland, C. L. (2003). How do offenders define bullying? A study of adult, young and juvenile male offenders. Legal and Criminological Psychology, 8(2), 159-173. doi: http://dx.doi.org/10.1348/135532503322362942

Ireland, J. L., \& Ireland, C. L. (2008). Intra-group aggression among prisoners: Bullying intensity and exploration of victim-perpetrator mutuality. Aggressive Behavior, 34(1), 76-87. doi: http://dx.doi.org/10.1002/ab.20213

Ireland, J. L., \& Monaghan, R. (2006). Behaviors indicative of bullying among young and juvenile male offenders: A study of perpetrator and victim characteristics. Aggressive Behavior, 32(2), 172-180. doi: http://dx.doi.org/10.1002/ab.20116

Ireland, J. L., \& Power, C. L. (2004). Attachment, emotional loneliness, and bullying behaviour: A study of adult and young offenders. Aggressive Behavior, 30(4), 298312. doi: http://dx.doi.org/10.1002/ab.20035

Ireland, J. L., \& Power, C. L. (2013). Propensity to support prison gangs: Its relationship to gang membership, victimisation, aggression and other disruptive behaviours. Psychology, Crime \& Law, 19(9), 801-816.

doi: http://dx.doi.org/10.1080/1068316X.2012.684057

Ireland, J. L., \& Qualter, P. (2008). Bullying and social and emotional loneliness in a sample of adult male prisoners. International Journal of Law and Psychiatry, 31(1), 19-29. doi: http://dx.doi.org/10.1016/j.ijlp.2007.11.005

Ireland, J. L., \& Rowley, J. (2007). Sectioned offenders presenting with enduring mental illness: A study exploring behaviours indicative of bullying. Aggressive Behavior, 33(5), 377-388. doi: http://dx.doi.org/10.1002/ab.20189

Ireland, J. L., \& Snowden, P. (2002). Bullying in secure hospitals. Journal of Forensic Psychiatry and Psychology, 13(3), 538-554. doi: http://dx.doi.org/10.1080/0958518021000019434

Kiriakidis, S. P. (2009). Prediction of bully and victim status among young male offenders. Hellenic Journal of Psychology, 6(1), 66-79.

Kõiv, K., \& Maasikas, L. (2014). Bullying among training school male adolescents and male adult prisoners: Descriptive analysis. In P. Triggs (Ed.), Handbook on bullying: Prevalence, psychological impacts and intervention strategies (pp. 215-258). New York: Nova Science Publisher.

Leddy, J., \& O'Connell, M. (2002). The prevalence, nature and psychological correlates of bullying in Irish prisons. Legal and Criminological Psychology, 7(2), 131140. doi: http://dx.doi.org/10.1348/135532502760274747

Listwan, S. J., Colvin, M., Hanley, D., \& Flannery, D. (2010). Victimization, social support, and psychological well-being: A study of recently released prisoners. Criminal Justice and Behavior, 37(10), 1140-1159. 
doi: http://dx.doi.org/10.1177/0093854810376338

McGurk, B. J., \& McDougall, C. (1991). The prevention of bullying among incarcerated delinquents. In D. Thompson \& P. K. Smith (Eds.), Practical approaches to bullying (pp. 130-139). London: David Fulton.

Monks, C. P., \& Coyne, I. (Eds.) (2011). Bullying in different context. Cambridge: Cambridge University Press. doi: http://dx.doi.org/10.1017/CBO9780511921018

Monks, C. P., Smith, P. K., Naylor, P., Barter, C., Ireland, J. L., \& Coyne, I. (2009). Bullying in different contexts: Commonalities, differences and the role of theory. Aggression and Violent Behavior, 14(2), 146-156. doi: http://dx.doi.org/10.1016/j.avb.2009.01.004

Nelson, A., Woodhams, J., \& Hatcher, R. (2010). Female prisoners' understanding of 'bullying' and their methods of coping: A multinational perspective. Psychology, Crime \& Law, 16(8), 649-670. doi: http://dx.doi.org/10.1080/10683160903025802

Palmer, E. J., \& Thakordas, V. (2005). Relationship between bullying and scores on the Buss-Perry aggression questionnaire among imprisoned male offenders. Aggressive Behavior, 31(1), 56-66. doi: http://dx.doi.org/10.1002/ab.20072

Power, K. G., Dyson, G. P., \& Wozniak, E. (1997). Bullying among Scottish young offenders: Inmates' self-reported attitudes and behavior. Journal of Community \& Applied Social Psychology, 7(3), 209-218. doi: http://dx.doi.org/10.1002/ (SICI)1099-1298(199706)7:3<209::AID-CASP419>3.0.CO;2-3

Smith, P. K., Pendleton, E., \& Mitchell, H. (2005). Bullying and anti-bullying policies: A young offender institution and an adult prison. In J. L. Ireland (ed.), Bullying among prisoners: Innovations in theory and research (pp. 109-125). Hove: Willan.

South, C. R., \& Wood, J. (2006). Bullying in prisons: The importance of perceived social status, prisonization, and moral disengagement. Aggressive Behavior, 32(5), 490-501. doi: http://dx.doi.org/10.1002/ab.20149

Spain, A. C. (2005). Bullying among young offenders: Findings from a qualitative study. In J. K. Ireland (ed.), Bullying among prisoners: Innovations in theory and research (pp. 62-83). Hove: Willan.

Tahir, M. A. (2011). Bullying among prison inmates in Pakistan: An exploratory of the problem. Bi-Annual Research Journal "Balochistan Review", 24(1), 1-16.

Turner, P., \& Ireland, J. L. (2010). Do personality characteristics and beliefs predict intra-group bullying between prisoners? Aggressive Behavior, 36(4), 261-270. doi: http://dx.doi.org/10.1002/ab.20346

Twemlow, S. W., \& Sacco, F. C. (2008). Why school anti-bullying programs don't work. Lanham: Rowman and Littlefield.

Wolff, S., Shi, J., \& Bachman, T. (2008). Measuring victimization inside prisons: Questioning the questions. Journal of Interpersonal Violence, 23(10), 1343-1362. doi: http://dx.doi.org/10.1177/0886260508314301

Wood, J., Moir, A., \& James, M. (2009). Prisoners' gang-related activity: The importance of bullying and moral disengagement. Psychology, Crime \& Law, 15(6), 569581. doi: http://dx.doi.org/10.1080/10683160802427786 


\title{
A descriptive analysis of bullying in prison: a study of male offenders in Estonia
}

\author{
Kristi Kõiv ${ }^{1}$ \\ a University of Tartu, Institute of Education
}

\section{Summary}

Research on bullying has grown during the last three decades in different contexts - schools, children's homes, dating relationships, the workplace, and prisons (Monks \& Coyne, 2011); and research into prison bullying has developed rapidly during the last two decades (Ireland, 2005a, 2011) beginning with extensive research in England, but now enlarging into several different countries. At the beginning of the research history into bullying, matters were concentrated on measuring the nature and prevalence of bullying among both sex adolescents and adults offenders with prevalent research done among male adult offenders (Ireland, 2005a). However, at present, research has focused on the intrinsic characteristics, personaldescriptive (e.g., age, length of sentence, type of offence), behavioural prison based behaviours (e.g., negative behaviour towards staff and rules, positive and drug-related behaviour), and prisoners' reactions to bullying.

This study sample explores bullying behaviour in one of Estonia's maximum security prisons. It has two core aims. The first to explore the nature and extent of indirect, direct and coercive behaviours indicative of bullying perpetration and victimisation among sample males and, secondly to explore the differences between bully-category membership, with regard to prisoners' personal and behavioural characteristics, and also with their reactions to the bullying.

The present study had the following research questions:

1. What is the nature and extent of indirect, direct and coercive bullying and victimisation among male offenders in Estonian maximum security prisons?

2. What are the differences between the bully-category (bullies, victims, bully/victims, not-involved) groups relating to their personal characteristics (age, sentence, length, offence type, total time spent in prison) behavioural characteristic (negative and positive behaviour, drug-related behaviour), and with their reactions to victimisation? 
Participants were adult men $(\mathrm{N}=110)$ who completed a self-reported questionnaire - the Direct and Indirect Prisoner Behaviour Checklist Revised (DIPC-R@: Ireland, 2002a; author's permission), which aims to measure direct, indirect and coercive forms of bullying. The DIPC-R specifically assesses physical, verbal, theft-related, sex-related, and psychological direct behaviours. The DIPC-R consists of 144 items, 56 representing victim items and 55 perpetration items. The remaining 33 items represent "filler" items and items measuring positive, negative and drug-related behaviour and reactions to victimisation. Participants were asked to indicate, in the past week, which behaviours they had carried out and which behaviours they had experienced. Translation, adaptation and validation of the DIPC-R were carried out during this research.

The findings of the present study showed that bullying is a widespread problem in Estonian male maximum security prisons. The first key question was not whether, but to what degree, bullying is a problem in one of the Estonian prisons. Using a self-reporting checklist that did not offer a definition of bullying to the participants, and listed a number of discrete behaviours defined as bullying behaviour, sampled adult male offenders reported that $57 \%$ had bullied others in the past week, with $63 \%$ admitting to being victimised.

Consistent with previous studies (e.g., Ireland, 2005a), it was revealed that indirect bullying occurred more frequently than direct bullying, showing that indirect perpetration was significantly more common than direct perpetration (accordingly: $39 \%$ versus $24 \%$ ) and indirect victimisation was significantly more common than direct victimisation (accordingly: $34 \%$ versus 19\%) among male offenders.

Consistent with previous research was the finding that verbal aggression represented the most frequently reported form of bullying and victimisation in prison. However, the present study also revealed that physical aggression was equally prevalent among sampled offenders.

Previous studies show that the group that was found most frequently within prison settings was the 'bully/victim' group with bullies as the smallest category (e.g., Turner \& Ireland, 2010). There was support for this tendency according to the previous research findings - more than $14 \%$ of male offenders were classified as bullies, $20 \%$ as pure victims, $43 \%$ as bully/ victims and $23 \%$ as not involved.

In relation to personal descriptive characteristics, previous findings were equivocal with such characteristics either not relating to group membership at all, or where they do, the findings were inconsistent (Ireland, 2005a). These research results supported previous findings that bully/victims had 
long term prison sentences (throughout a lifetime and current detention) compared with those who reported not involvement of bullying behaviour, but the increased amount of imprisonment was characteristic also for pure victims compared with other groups. In relation to age as a personal characteristic, bully/victims and pure victims tended to be younger versus pure victims and not involved offenders, who tended to be older. There were no differences in ethnicity and differences in offence type between the four bully-category groups.

Findings in relation to behavioural characteristics have supported previous studies (Ireland, 2011) revealing that bully/victims had incidents of negative behaviour, especially towards staff, compared with those not involved. There were no differences between bully-category groups concerning with involvement in prison-based drug-related behaviour.

Indeed the "response to victimisation" items indicated that bully/victims and pure victims were more likely to report defending themselves against another prisoner and be involved with other activities to stop bullying, whereby across all bully category membership there was a tendency to use avoidance responses. Self-harm had the lowest frequency response to victimisation and did not differentiate victim-bully status groups. This study found that bully/victims were more prone than pure bullies to report that they would respond to victimisation with aggression; and victims of bullying were more prone to report that they would respond to victimisation with emotional reactions.

Overall, the findings provide evidence of consistency with previous research regarding the nature and prevalence of prison bullying, revealing also personal and behavioural predictors of classification mainly into the bully/victim versus not-involved category. It highlights the need for longitudinal research specifically into exploring the relationships between the change of bully-category membership, and to plan and use effective interventions in the area of prison bullying.

Keywords: bullying, adult male offenders self-reported bullying behaviour, DIPC-R 